expenses are provided in addition. The Carlsberg-Wellcome fellowships are arranged with the Carlsberg Foundation in Copenhagen; the Wellcome-Swedish fellowships are provided jointly by the Medical Research Council of Sweden and the Wellcome Trust. Candidates in the United Kingdom can obtain further information from the Secretary, the Wellcome Trust, 52 Queen Anne Street, London, W.1. Completed applications must be submitted. by April 9, 1966.

\section{Guinness Awards for Science and Mathematics Teachers}

THe Guinness Awards for Science and Mathematics Teachers are now being extended to Africa. They are being carried out in association with the Department of Education in Tropical Areas of the University of London Institute of Education, Malet Street, London, W.C.1, together with the assistance of a number of Departmonts and Institutes of Education in Africa, Ministries of Education and the British Council.

\section{Nature Subscriptions}

Ix is regretted that the charges for direct postal subscriptions to Nature printed on the back page of the index for Volume 207 are incorrect. The present charges are:

\begin{tabular}{lrlllrl} 
& \multicolumn{3}{c}{ Inland } & \multicolumn{4}{c}{ Overseas } \\
12 months & $£ 14$ & 0 & 0 & $£ 13$ & 15 & 0 \\
6 months (26 issues) & $£ 7$ & 0 & 0 & $£ 6$ & 17 & 6 \\
3 months (13 issues) & $£ 3$ & 10 & 0 & $£ 3$ & 8 & 9
\end{tabular}

Payment from abroad should be made by International Money Order or by cheque payable to Macmillan (Journals), Ltd. (Macmillan (Journals), Ltd., is now at 4 Little Essex Street, London, W.C.2.)

\section{Organization of the Scientific Civil Service}

Ix has been brought to the Editor's notice that the fourth paragraph of the review of the Report of the Tennant Committee, published on p. 113 of the December 18, 1965, issue of Nature, is open to misinterpretation. The figures given in the first sentence of the paragraph relate to the unestablished staff referred to in the preeeding paragraph. Thus, in the scientific and experimental officer classes taken together, 80 per cent of the officers serving in a temporary or unestablished eapacity have been employed in the Civil Service for 5 years or less, and in the scientific officer class 60 per cent and in the experimental officer class 50 per cont of the unestab. lished staff have been omployed for $2 \cdot 5$ years or less.

\section{University News:}

Edinburgh

Dr. R. M. CoRMack has been appointed senior lecturer in statistics. The following lecturers have also been appointed: Dr. C. P. Mayers (pathology); Mr. D. A. Williams, Mr. C. W. D. Peare and Mr. E. F. Harding (statistics).

London

A CHaIr and Research Group in Traffic Studies have recently been established at University College, London, and Prof. R. J. Smeed, formerly deputy director (traffic and safety) of the Road Research Laboratory, and more recently chief scientist at the Ministry of Land and Natural Resources, has been appointed holder of the chair and director of the Group.

Manchester

Phof. D. H. Valentine, professor of botany in the University of Durham, has been appointed George Harrison professor of botany and director of the Experimental Grounds in succession to Prof. C. W. Wardlaw, who is retiring on September 30. The following appointments have also been made: Readers, Dr. A. Allsopp (cryptogamic botany); Dr. K. J. Dormer and Dr. E. W. Simon (botany); Dr. W. C. E. Higginson, Mr. O. S. Mills, Mr. N. L. Paddock and Dr. G. F. Smith (chemistry); Dr. F. P. Stainthorp (chemical engineering); Senior Lecturers,
Dr. F. R. Jevons (biological chemistry); Dr. L. Barden (soil mechanies); Dr. R. A. J. Shelton (metallurgy); Dr. G. A. Lumb (medical chemistry); Dr. G. Taylor (immunology); Dr. G. C. Wood (chemical engineering); Dr. W. D. Humpage, Dr. D. C. Northrop, Dr. L. M. Wedepohl, Dr. T. E. Broadbent and Dr. D. Tipping (electrical engineering); Mr. S. V. Fagg (mathematics); Mr. N. D. Whitehouse (mechanical engineering); Dr. I. G. Edmunds (physics); Lecturers, Dr. S. Dunstan, Dr. M. G. Barlow and Mr. M. J. Ware (chemistry); Dr. G. S. Taylor (botany); Dr. J. A. Joule (organic chemistry); Mr. D. G. Buchanan, Mr. B. E. Jones and Mr. P. Swarbrick (electrical engineering); Dr. J. M. Anketell and Mr. J. Esson (geology); Mr. R. D. Gregory, Mr. J. A. King-Hele, Mr. J. T. Smith, Dr. G. Christensen and Dr. D. A. Lavis (mathematics); Mr. P. Wilkes (metallurgy); Dr. J. M. Irvine (theoretical physics); Mr. J. E. B. Ponsonby (radio-astronomy); Dr. R. T. W. L. Conroy (physiology); Dr. A. J. Barson, Dr. A. Garner and Dr. R. S. Kirk (pathology); Mr. G. H. West (polymer and fibre science); Dr. N. Jones and Mr. J. T. Turner (mechanical engineering).

\section{Announcements}

Mr. J. H. Nicholas and Mr. M. E. Burt have been appointed deputy chief scientific officers at the Road Research Laboratory: Mr. Nicholas has been appointed head of the Construction Division, and Mr. Burt head of the Design Division.

Mr. H. Ll. D. Pugh and Mr. A. H. Low have been awarded the W. H. A. Robertson Medal and Premium for 1965 by the Council of the Institute of Metals, for their paper, "The Hydrostatic Extrusion of Difficult Metals", which was published in the March 1965 issue of the Journal of the Institute of Metals.

THE 1966 congress of the Institute of Animal Technieians will be held in the University College of North Wales during March 31-April 1. Further information can be obtained from Mr. A. E. Mundy, 5 Ouse Bridge Drive, Carlton, Nottingham.

THe first meeting of the newly formed North East Section of the Society for Analytical Chemistry will be held in Durham on March 24. Further information can be obtained from the Society for Analytical Chemistry, 14 Belgrave Square, London, S.W.1.

A sYMPosIum on "Seottish Estuaries", arranged by the Institute of Biology (Scottish Branch), will be held in the University of Strathelyde during March 31-April 1. Further information can be obtained from Dr. E. J. Perkins, Department of Applied Microbiology and Biology, Biology Annexe, University of Strathclyde, George Street, Glasgow, W.1.

A Jorn' meeting of the North of England Section of the Society for Analytical Chemistry and the Leeds University Union Chemical Society will be held in the University of Leeds on March 18. Prof. C. L. Wilson will deliver a paper on "Analysis Reborn". Further information can be obtained from the Society for Analytical Chemistry, 14 Belgrave Square, London, S.W.1.

A CONFERENCE on "Nuclear Structure and Elementary Particles", arranged by the Nuclear Physics Sub-committee of the Institute of Physics and the Physical Society, will be held in the University of Oxford during March 30April 1. Further information can be obtained from the Meetings Officer, Institute of Physics and the Physical Society, 47 Belgrave Square, London, S.W.1.

A symposiom on "Tape Recording of Biological Signals", organized by the Scottish Section of the Institution of Electronic and Radio Engineers and the Scottish Electronics and Control Section of the Institution of Electrical Engineers, will be held in Edinburgh on March 29. Further information can bo obtained from Mr. P. M. Elliott, 21 Craigmount Loan, Corstorphine, Edinburgh 12. 